\title{
未改良の埋立地や低平地の地盤沈下対策 Measures of Subsidence in Natural or Artificial Low Land without Ground Improvement
}

\section{まえがき}

我が国は, 世界でも有数の地震多発国である.同時に, 台風や豪雨による災害に見舞われる頻度が極めて高いことは, この数十年間, 特に近年被った災害履歴を振り返れば疑う余地のないところである. 国内のどこであっても災害に見舞 われる可能性はあるが, 山がちで四方を海に囲まれた地形的な特徵から, 人々は急峻な河川の下流域に生活の場を求め, 河川・海路輸送を発達させて都市化を進め産業を発達させてきた。 この河川下流域は, 地形分類でいうところの汇濫平 野, 旧河道, 湿地など, いわゆる低平地であり, 干拓地や埋立地である.これらの土地は, 軟らかくて変形しやすい, いわゆる軟弱な粘性土地盤上に造成されたものも多く，当時の地盤改良技術の未熟さや，急速な社会の変化に対応する ため, 地盤改良がされていないケースも多くある。このような場所では, 今日でも地盤沈下が収束せず，じわじわと沈 下が進行している場所も少なくない, また, 地盤沈下が収束するかに見えていた埋立地や低平地においても, 特に地下 水の汲み上げや土地の嵩上げ，さらには地震動などの外力によって地盤沈下が加速するケースも見受けられる.

本講座を担当する地盤改良部門委員会は, 1962 年 11 月に土質安定材料委員会として発足以来, 約 55 年にわたって 地盤の改良技術に関係する多くの課題に取り組み, 調查・研究活動を推進してきた.この委員会の活動のひとつとして, 2014 年 4 月より当講座のタイトルである「未改良の埋立地や低平地の地盤沈下対策研究会」を設置して, 未改良の埋 立地や低平地の現状を調査し, 地盤沈下を含むこれらの地域の課題を抽出, 将来に向けての対策方法を提案することを 主目的に活動してきた。この間, 沈下被害が顕著な国内 5 箇所（長野県諏訪市, 宮城県塩䆞市, 佐賀県白石町, 山形県 南陽市，北海道江別市）の現地視察を行い，地域每の被害や地盤の特徵などについての調査・研究を行った。

本講座では, この未改良の埋立地や低平地の地盤沈下対策研究会の活動を通して得られた成果について, 5 回にわた り以下の担当者とタイトルで解説する.

第 1 回「未改良の埋立地や低平地の現状と課題」

第 2 回「地盤沈下のメカニズム」

第 3 回「地盤沈下と地域地盤特性」

第 4 回「代表的な地盤沈下対策方法」

第 5 回「地盤沈下対策の新たなトレンド」

\author{
今西 肇 (東北工業大学), 杉山太宏 (東海大学) \\ 重松宏明（石川工業高等専門学校） \\ 大島昭彦 (大阪市立大学大学院) \\ 日置和昭 (大阪工業大学) \\ 今西 肇 (東北工業大学), 杉山太宏 (東海大学)
}

\section{1.未改良の埋立地や低平地の現状と課題 \\ 今西 肇* 杉山太宏** \\ I : Current Status and Issues in Natural or Artificial Low Land without Ground Improvement}

by

\author{
Hajime IMANISHI * and Motohiro SUGIYAMA **
}

Key words: Unimproved Ground, Reclaimed land, Low land, Ground Settlement, Ground Water

\section{1 はじめに}

日本の国土は約 38 万 $\mathrm{km}^{2}$ で，アメリカや中国など大 陸諸国（約 1000 万 $\mathrm{km}^{2}$ ） と比較して，「小さな島国」と 表現されることも少なくないが，世界 200 数十力国の中 では面積の広い方から 62 位と上位 $1 / 3$ 以内にある.この 「小さな島国」である日本の地形は，春梁山脈が背骨の ごとく列島中央を貫き，「山地」，「丘陵地」ならびに「台 地」を合わせた面積は実に国土の 8 割を超える。また，
国土面積に対する森林の面積はおよそ 3 分の 2 で, ほと んどの人々が河川下流域から海岸に面した「低地」に居 を構え, 生活基盤（インフラ）の整備を行ってきた。 そ の結果として国内の都市部はこの低地に発達してきた. 都市部では, 海浜部を埋立て新たな土地を造成し, 港湾 の整備, 居住地, 産業団地を形成して産業振興が行われ た. 既存埋立地の中には, 低地であるがゆえに軟弱な粘 性土地盤上に造成されたものも多く, 軟弱地盤の改良が なされていない箇所も少なからず見受けられる. 1960 年

+ 原稿受理 平成 30年 10月 22日 Received Oct. 22, 2018@2019 The Society of Materials Science, Japan

* 正会員 東北工業大学名誉教授 †982-8577 仙台市太白区八木山香澄町 Emeritus Professor, Department of Civil Engineering and Management, Tohoku Institute of Technology, Taihaku, Sendai, 982-8577

** 正会員 東海大学工学部土木工学科 广259-1292 平塚市北金目 Department of Civil Engineering, Tokai University, Kitakaname, Hiratsuka 259-1292 
代の高度経済成長期に軟弱地盤上に造成工事が行われ， その後 50 年近くが経過した今日でもなお地盤沈下が収 束せずに進行しているケースも少なくない。ささらに，地 盤沈下が収束するかに見えていた埋立地において，外力 の増加, 特に地震動により粘土構造が破壊され, 地盤沈 下が加速するケースも散見されている.

このような現状を鑑み, 未改良の埋立地や低平地の現 状を調査して，地盤沈下を含むこれらの埋立地の課題を 抽出し, 将来に向けた地盤の沈下と変形に対する対策方 法を提案することを目的に, 2014 年 4 月に地盤改良部門 委員会内に「未改良の埋立地や低平地の地盤沈下対策研 究会」(委員長：今西肇）を設置した. 当研究会は 18 名 の委員で構成され，3つのワーキングによって 4 年間に わたり調查・研究活動を行ってきた. 各調查研究ワーキ ングでは，未改良の埋立地や低平地の

(1) 現状と課題

(2) 地盤構造や地盤特性

(3) 地盤沈下を含む課題と対策方法

をテーマとしている.

本講座では,「未改良の埋立地や低平地の地盤沈下対 策研究会」が取り組んできた内容のうち，上記ワーキン グ(1)の報告として，はじめに「未改良の埋立地や低平地」 を定義する. 次に, このような地域の現状と課題につい て述へ，未改良の埋立地や低平地の沈下事例とその対策 事例を紹介寸る．最後に，次号からの各回講座の内容を 概説する.

なお，本講座の第 2,3 章の内容は，日本材料学会誌 「材料」 2016 年 10 月号の講座「我が国における地盤改 良の変遷 3 .未改良の埋立地や低平地における地盤沈下 への対応 (今西肇・杉山太宏) 1)」で報告したものに， 一部加筆・修正したものである.

\section{2 未改良の埋立地や低平地の定義 ならびに現状と課題 ${ }^{1)}$}

\section{$2 \cdot 1$ 未改良の埋立地や低平地の定義}

「未改良の埋立地や低平地」とは，漁港や工業港，耕 作地や居住地としての埋立地, 沿岸部の低平地, 内陸部 の盆地などを言い，埋立てられたり嵩上げや盛土が施工 されたりして, 現在何らかの経済活動がなされている場 所のことを指す.

このような場所は，地下に軟弱な粘土地盤が厚く分布 し堆積していることが多いが，種々の社会経済活動を実 施するために，地盤沈下などへの対策がすでに行われて いる場所でもある。しかしながら，供用開始時に利用が 決まっていなかった場所や, 地盤改良や基礎構築がなさ れた箇所の近接部などは, 未改良の地盤が多く存在し, 埋立地や低平地には未改良部と沈下対策実施部とが混 在しているのが実情である.

このような観点から本研究会では, 「未改良の埋立地 や低平地」を，「全く地盤改良がなされていない埋立地 や低平地」ならびに地盤対策として地盤改良や基礎構築 がされてはいるが「未改良部分も多く残っている埋立地 や低平地」と定義した.

\section{$2 \cdot 2$ 未改良の埋立地や低平地の現状}

環境省，水・大気環境局の「平成 28 年度 全国の地盤 沈下地域の概況」によると ${ }^{2)}$, 平成 28 年度に地盤沈下の 測定のための水準測量が実施された地域は, 21 都道県 29 地域である.ほとんどの地点は, 地下水の過剩な採取

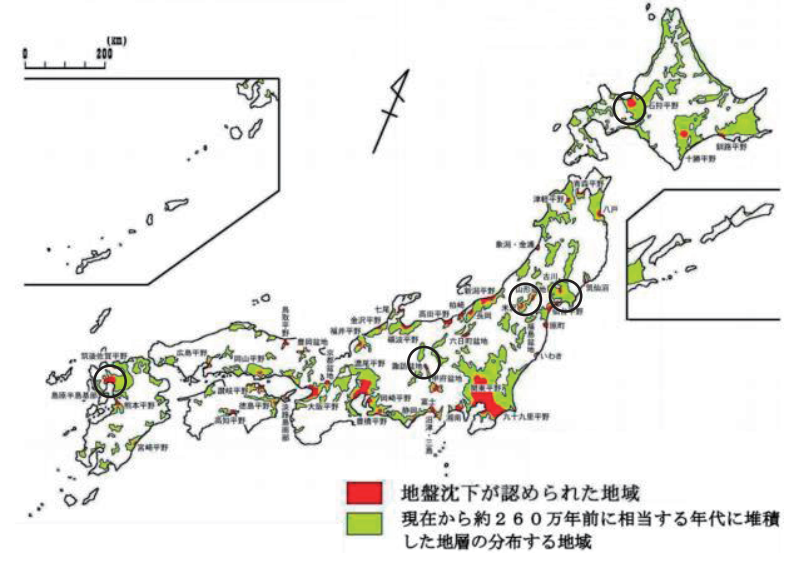

図 1 全国地盤沈下地域 ${ }^{2)}$

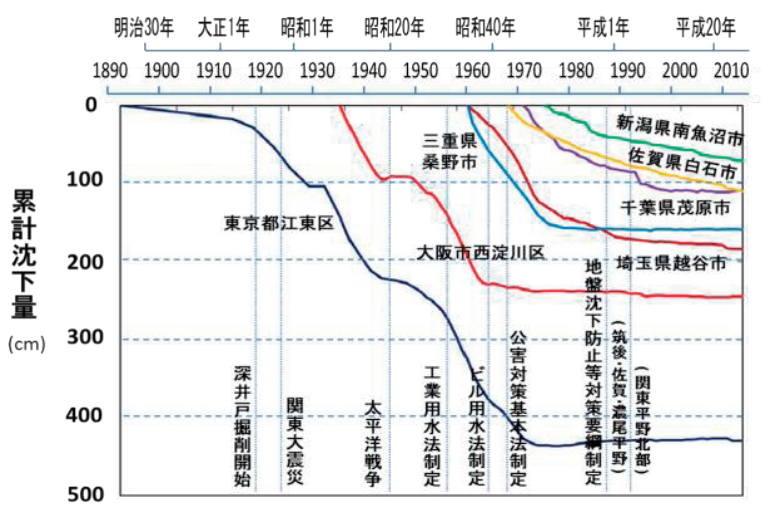

図 2 代表的地域の地盤沈下の経年変化 ${ }^{2)}$

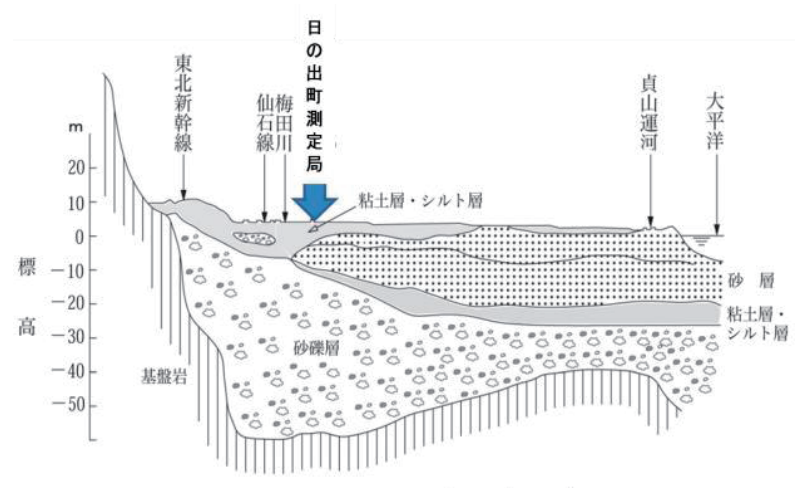

図 3 仙台市における東西方向の地質断面図 ${ }^{3)}$

により地下水位が低下し，粘土層などの軟弱な層を圧密 させることにより地盤沈下が生じている. 図 1 および図 2 は, 全国の地盤沈下地域と代表的地域の地盤沈下の経 年変化を示す。

一方, 平成 23 年 3 月 11 日には東北地方太平洋沖地震 による広範囲な地殼変動が発生した. その後の地盤沈下 観測によると, 軟弱層が堆積する場所では地盤沈下が加 速した事例が報告されている。

図 3 および図 4 は仙台市環境局が実施している地下 水位の低下の影響を調べたもので，宮城野区の地盤沈下 の計測結果である ${ }^{3)}$ 。これによると， $10 \mathrm{~m}$ 程度の厚く堆 積した粘土・シルトからなる軟弱粘性土層の圧密沈下速 


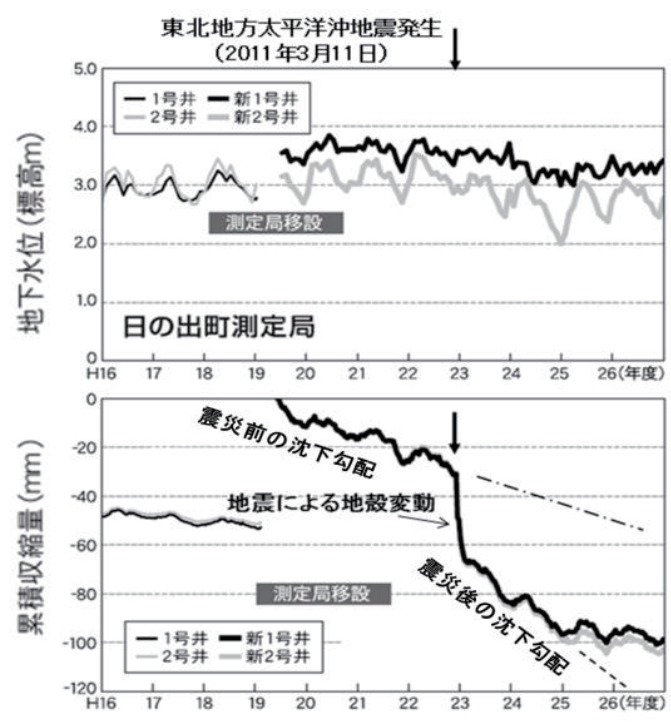

図 4 仙台市宮城野区日の出町の地盤沈下 ${ }^{3)}$

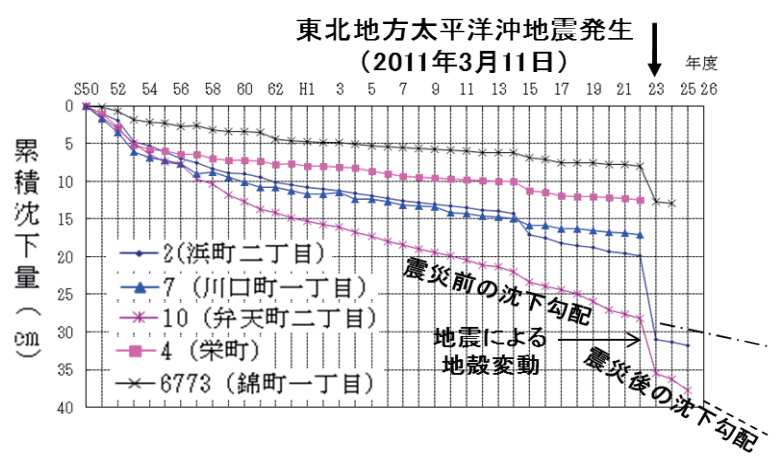

図 5 気仙沼市弁天町の地盤沈下 ${ }^{4)}$

度が，震災前後で地下水位の変動がないにもかかわらず, 大きく異なっていることがわかる．また，宮城県の資料 によると ${ }^{4)}$, 気仙沼市弁天町の埋立地でも図 5 に示すよ うに，地震前後で地盤沈下速度の違いがあることが報告 されている。このような現象は, 過去の地震においても 観測されており, 地殼変動の影響, せ九断変形, 水圧増 加減少に伴う圧密沈下の影響などが考えられるが，今の ところ明確な理由は不明である。

環境省の水・大気環境局による自治体へのアンケート 調查によれば 2), 22 都道県 29 地域のうち, 地盤沈下と 地震の関係について，「影響がない」としたものは 15 県 20 地域であり，「影響がある」とした地域は 1 件 1 地域 であった。それ以外の 7 道県 8 地域は「影響があるかな いかわからない」と答えている。これは，仙台市や気仙 沼市の例のように記録が取れている場所もあるが，地殼 変動や津波などによる破損のため, 測定できていない場 所も多いと思われる.

\section{$2 \cdot 3$ 未改良の埋立地や低平地の課題}

2.1 に定義されている「未改良の埋立地や低平地」は これを構成する地盤とその利用形態によって, 次のよう な課題がある。

(1) 地盤の課題

(1) 粘土の工学的な性質の地域差が大きい.

(2) 粘土層はその成分や形成の仕方によって性質が千 差万別である.
(3) 地下水位低下による地盤沈下は広域的に発生する ため，限定的な対策がとりにくい.

(4) 数十年にわたる長期の地盤沈下が発生する.

(5)間隙が大きいために, 排水や載荷などの物理的な改 良による粘土の圧縮量は数十パーセントに達する.

（6) 地震力による粘土の構造破壊による地盤沈下が発 生する.

(2) 地盤の利用形態による課題

(1) 地盤沈下による構造物や既設基礎杭の抜け上がり が発生する。

(2) 道路部の嵩上げによる地盤沈下が進行する.

(3) 工場などの立て替えにおける既存基礎杭などの処 理が発生する。

(4) 基礎杭支えられた工場建物と道路の段差がある.

(5) 地中に埋設された上下水道管やガス管の沈下が建 物境界で不当沈下などが発生して折れ曲がる.

したがって, 未改良の埋立地や低平地の地盤沈下の対 応を検討するにあたり地盤改良工法を用いる場合には， 経済性を考慮した地盤改良技術の応用や, 既存の地盤改 良技術を複数利用する新たな地盤改良システムの開発 が必要である。また, 粘土の種類によっては, 化学作用 による改良効果が不十分な場合もあり, 改良材と粘土の 相性も考慮する必要がある。

\section{3 軟弱地盤に生じた沈下の実態について}

研究会では, 国内で観測された沈下被害が顕著な 5 箇 所 (宮城県塩䆞市, 長野県諏訪市, 佐賀県白石町, 山形 県南陽市, 北海道江別市, 図 1 に○印で示す) の現地視 察を行い, 地域毎の被害や地盤の特徵などについて調査 研究を行った. 本章では, 視察地で撮影した地盤沈下に よる被害を紹介するとともに, 研究会を設置するきっか けともなった宮城県塩篭市の地盤沈下の概要について

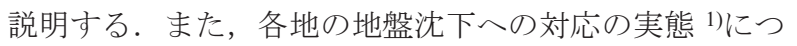
いて簡単に述べる。

\section{$3 \cdot 1$ 視察地（塩鼌市・諏訪市・白石町・江別市）の 沈下被害}

図 6 から図 8 は宮城県塩䆞市新浜地区, 図 9 から図 14 は長野県諏訪市内, 図 15 から図 17 は佐賀県白石町, そ して図 185) から図 19 は北海道江別市内でそれぞれ撮影 した沈下被害を受けた施設や建造物, 道路の様子を示し たものである.

図のキャプションに概要を説明しているが，塩鼌は， 軟弱な海底粘土地盤を埋立て造成された土地で, 無対策 で行われた粘土地盤の埋土荷重による沈下が主要因で ある。

諏訪は, “すくも層” と呼ばれる高含水比で極めて軟 弱な有機質腐植土層が堆積しており, 温泉や地下水の波 み上げ，造成工事による盛土や構造物荷重が沈下の要因 となった。

佐賀の有明海沿岸には，有明粘土層と呼ばれる有機分 を多く含み含水比および鋭敏性が極めて高い軟弱な粘 土が厚く分布する. 平野部の勾配が緩く, 河川の感潮域 が中流まで及ぶため, 古くより地下水が水源として利活 用された。この地下水の汲み上げが沈下の主要因である. 北海道の石狩川流域には超軟弱な泥炭層が厚く堆積 している．札幌～岩見沢間の高速道路建設時には，江別 において泥炭地盤の沈下挙動を調べるために試験盛土 が施工された地区である。 


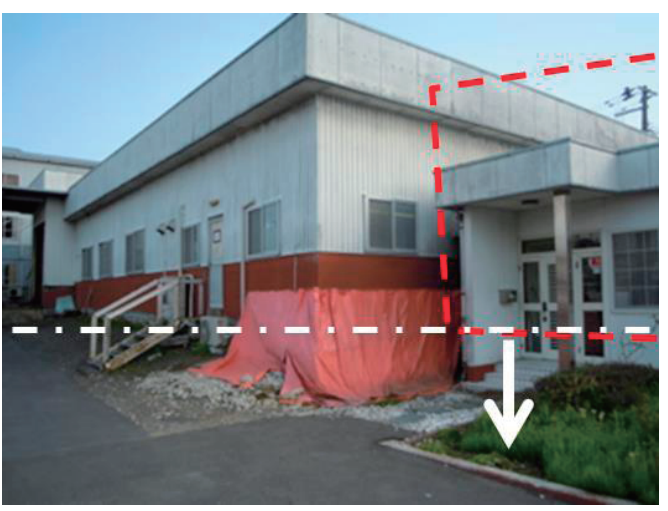

図6 塩窂市白浜地区の建物沈下 （建物左：杭基礎，右：ベ夕基䃈）

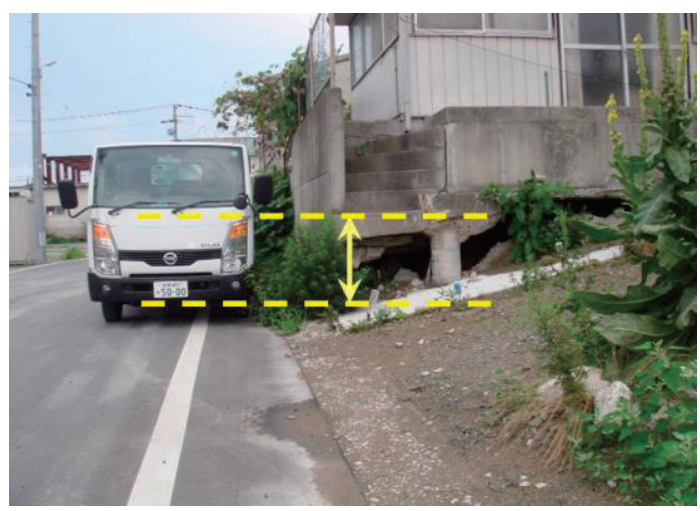

図 7 塩璂市白浜地区の建物沈下 (基礎杭が約 $80 \mathrm{~cm}$ 露出)
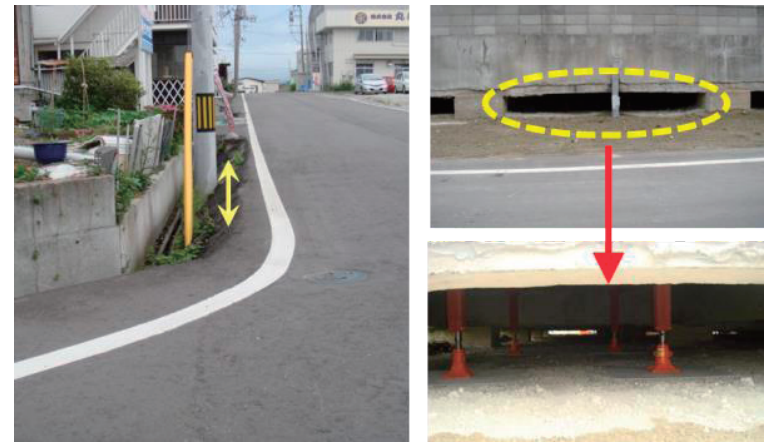

図 8 塩窠市白浜地区の道路と建物沈下 (左：度重なる道路のかさ上げ, 右 : 建物地中梁 をジャッキアップ)

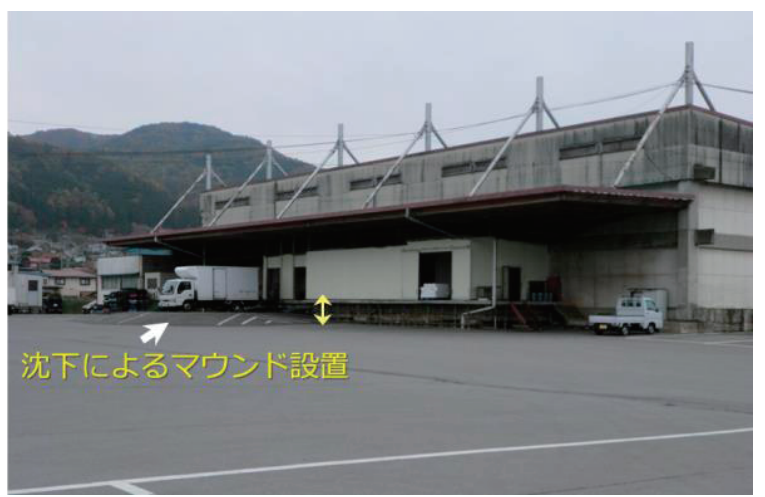

図 9 諏訪市公設地方卸売市場周辺地盤の沈下 1 （荷物の積み下ろしのため局所的にマウンドを設置）

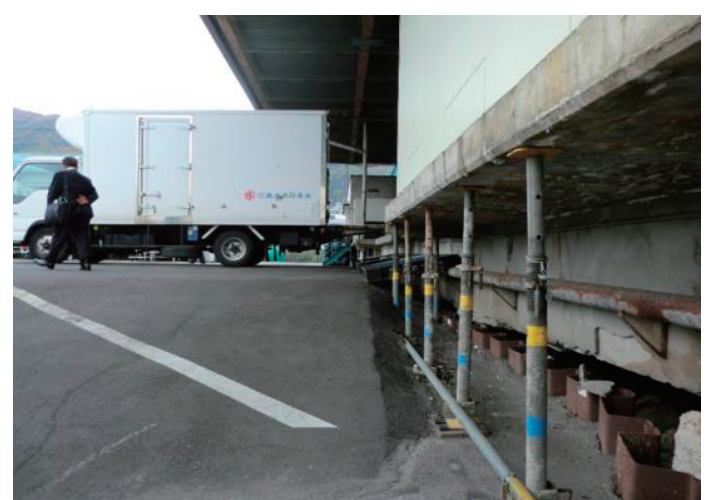

図 10 諏訪市公設地方卸売市場辺地盤の沈下 2 (図 9 マウンドの近景)

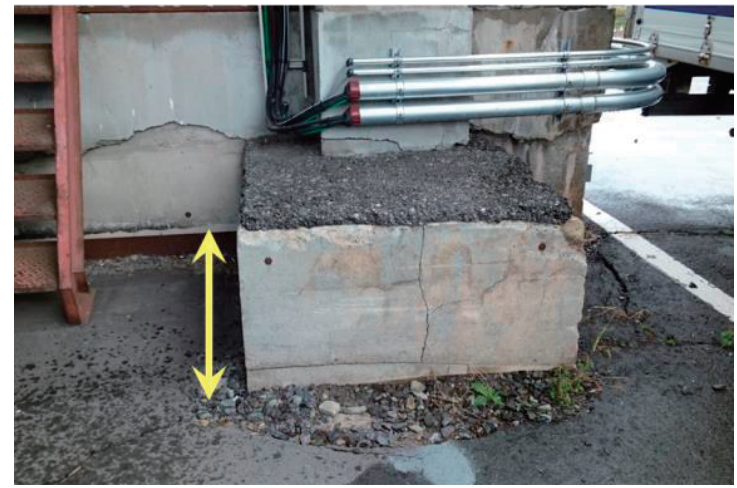

図 11 諏訪市公設地方卸売市場辺地盤の沈下 3 (フーチングの露出)

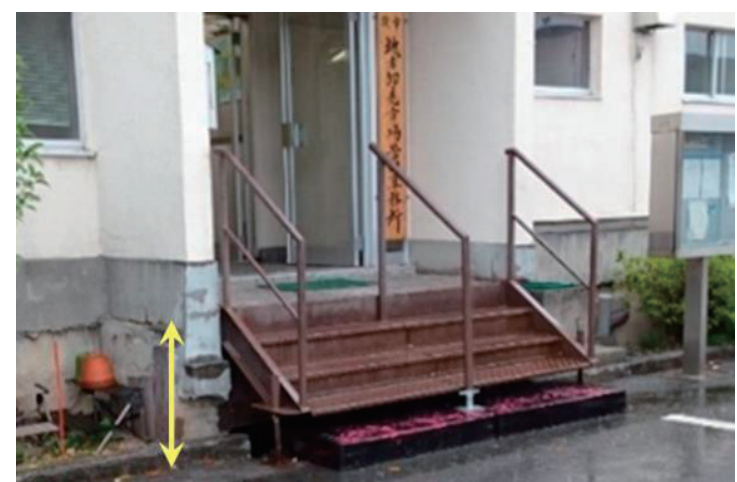

図 12 諏訪市公設地方卸売市場事務所入口 （沈下によって 3 段の鋼製階段設置後，更に 1 段追加された）

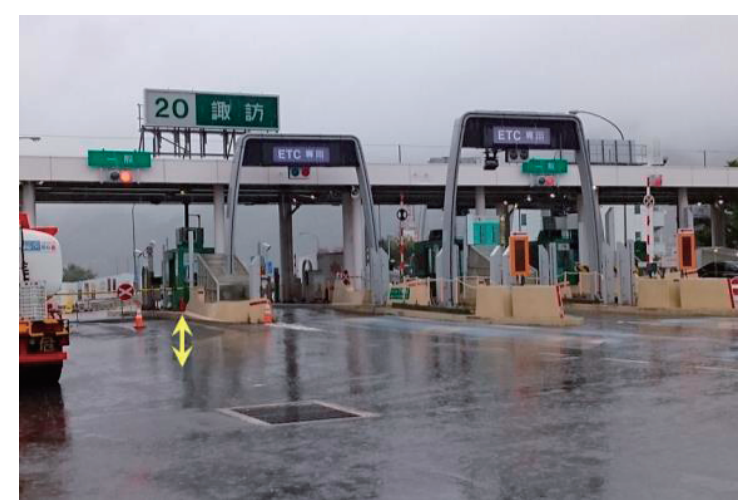

図 13 諏訪 IC 料金所付近の沈下 1

(ゲート周辺抜上がりのためオーバーレイが繰り返された） 


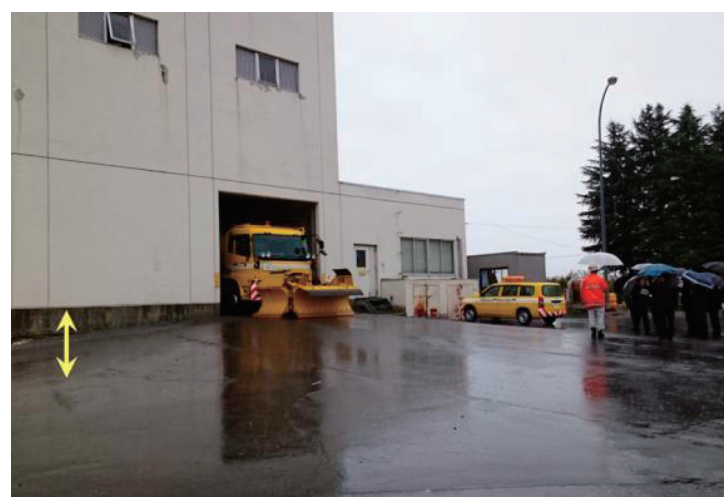

図 14 諏訪 IC 料金所付近の沈下 2 (除雪車用格納庫のマウンド)

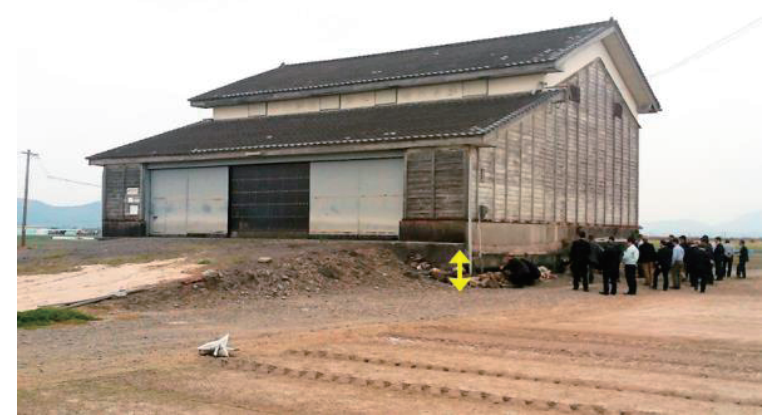

図 15 佐賀県白石町の農業倉庫周辺の沈下 1 (農耕機用のマウンドが土盛りされている)

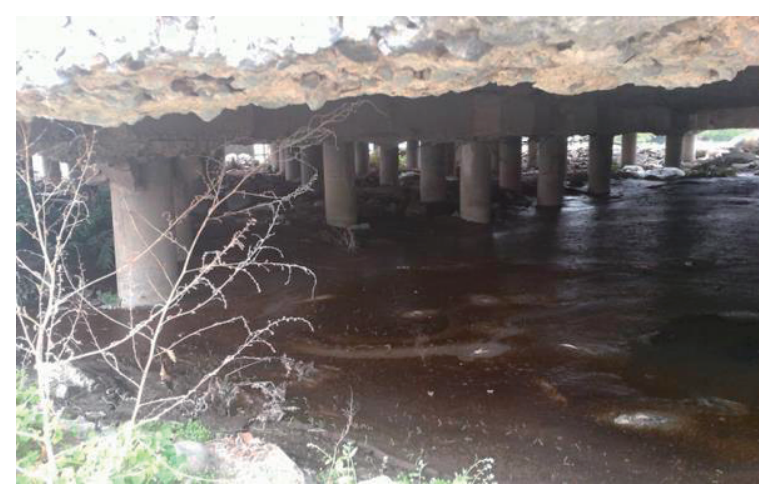

図 16 佐賀県白石町の農業倉庫周辺の沈下 2 (抜け上がった PC 杭と地中梁)
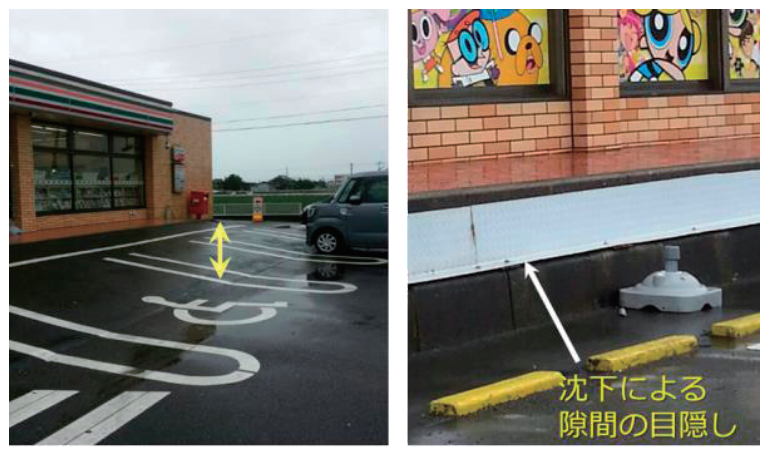

困 17 佐賀県白石町のコンビニストア周辺の沈下 （駐車場のためのマウンド，隙間の目隠しの設置）

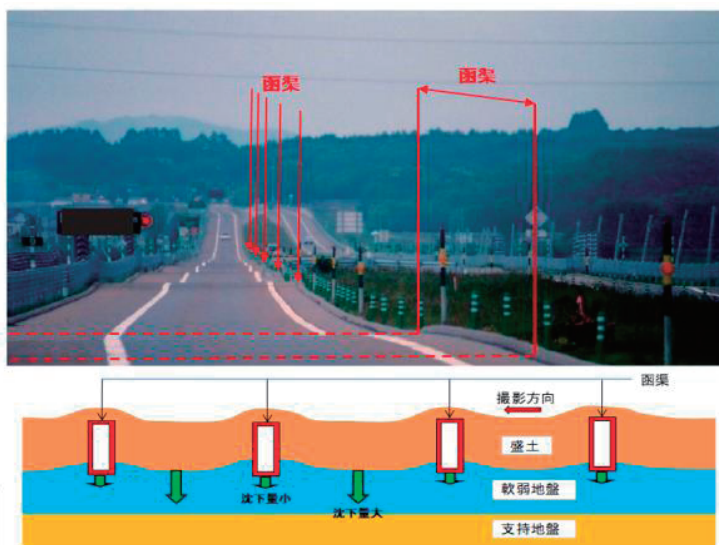

図 18 泥炭地盤上に建設された道路沈下 5)に加筆 （函渠の有無による沈下量の差により洗濯板状に沈下）

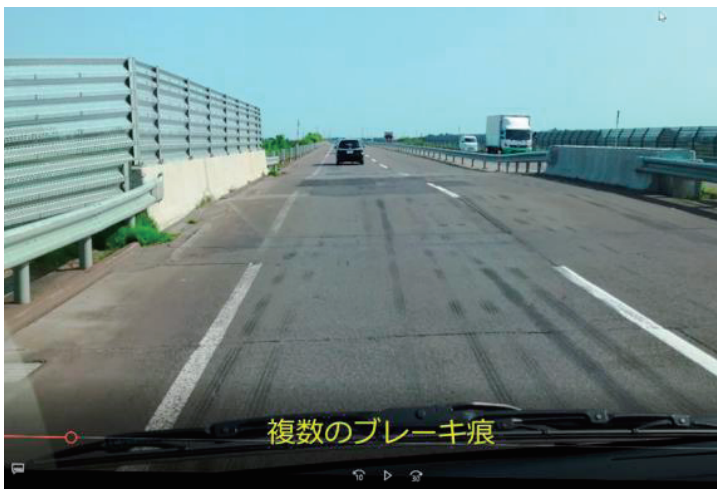

図 19 江別市三原道路のボックス部段差

（近づいて段差に気付いて踏んだと思われるブレーキ痕）

\section{$3 \cdot 2$ 塩鼌市新浜地区の地盤沈下と対応 ${ }^{1)}$}

（1）地形，地質ならびに地盤沈下の概要 $\left.{ }^{6}\right)$

塩鼌市新浜地区は，40 年前（1970 年代）に軟弱な粘 土地盤が厚く堆積している海底部を未改良のまま埋め 立てて造成された土地であり，主に工場などが立地して いる. 地盤構造は新第三紀中新世松原湾層群網尻層が基 盤岩となっており, その上を海底に堆積した粘性土が覆 い，表層部には埋立土および盛土が分布する．新浜地区 には $N$ 值がゼロの極めて軟弱な粘性土が最大 $20 \mathrm{~m}$ の厚 さに分布しており, 自然含水比は $150 \%$ 越えるものが 多く, 土粒子の密度は $2.50 \mathrm{~g} / \mathrm{cm}^{3}$, 土の湿潤密度は 1.25 $\mathrm{g} / \mathrm{cm}^{3}$ と小さい。また，目視によると有機物が多く含ま れている. 塑性指数も最大で 150 と高く, 液性限界が $200 \%$ 超えるところもある.

(2) 地盤沈下の概要

図 20 は, 宮城県内で観測された地盤沈下の経時変化 である。当該地区では（図中の塩窼市新富町）昭和 49 年から平成 22 年までに $30 \mathrm{~cm}$ を越える沈下が発生して おり (図 6 〜図 8 ), 1978 年と 2011 年の 2 度の地震直後 には, 沈下が急増している.この地震による急激な沈下 は地款変動によるものと考えられるが，その後の沈下 速度が地震前と比べて大きくなっていることが注目さ れている6).

(3) 地盤沈下への対応例

塩鼌市新浜地区においては，水産加工場建設に当たり 基礎杭によって支えられる設計となっていたが，リアス 式海岸では基盤岩深度の不陸が大きく, 打ち止め位置の 確認が困難であった。 また, 埋立地ゆえに岩塊等が不規 則に混入している恐れもあり，杭による支持層への支持 


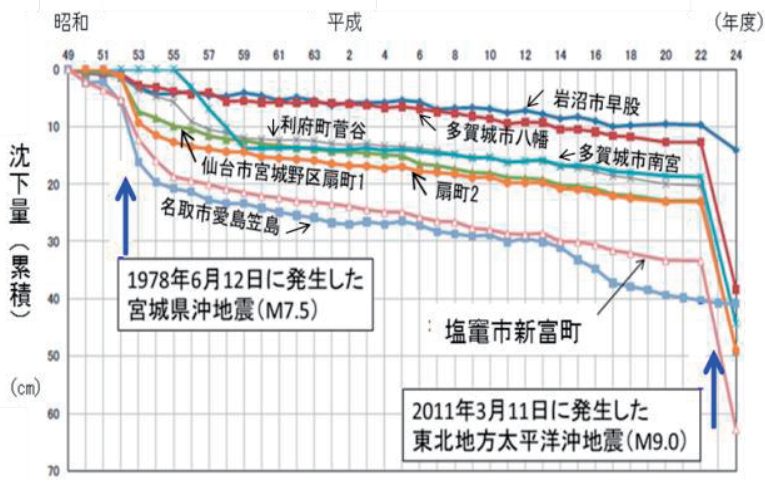

図 20 昭和 49 年からの宮城県内の地盤沈下量 ${ }^{6}$

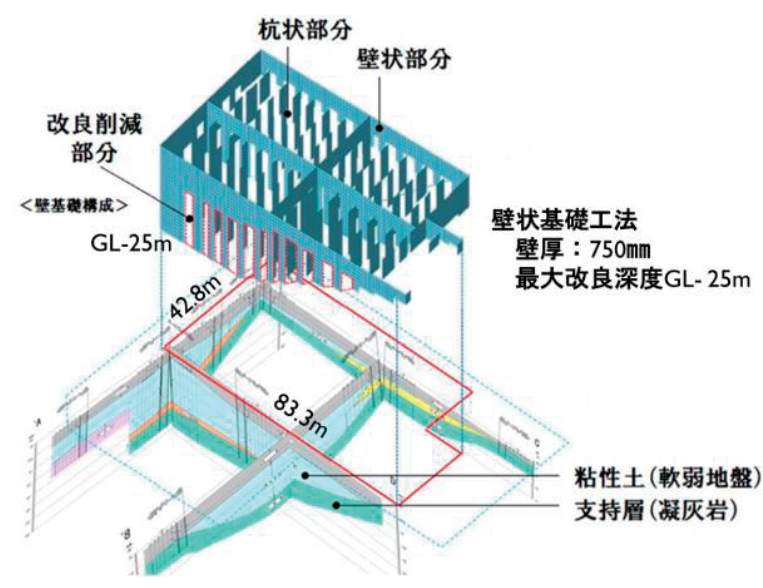

図 21 壁状基礎工法による建物基礎の構築例 6)

を確保することが難しいと判断された。そこで，杭基礎 に代わる地震動にも強い基礎工法の選定を実施した結 果，強度のばらつきが少ない地盤改良工法を用いた壁状 基礎構造とすることとした。図 21 は実施した壁状基礎 工法の概要図である。

なお，諏訪地域で古くから採用されてきた代表的沈下 対策工法として，松丸太をいかだ状に組んだ浮基礎工法 の「いかだ工法」や「杭打ち工法」が挙げられる. 昭和 3 年(1928 年)に建設された鉄筋コンクリート 2 階建ての

“片倉館”の基礎には，長さ $5.5 \mathrm{~m}$ の松丸太が合計 2600 本打ち込まれている。昭和 19 年に震度 6 を観測して諏 訪盆地の住居や建造物に甚大な被害を与えた東南海地 震にも，片倉館は耐えることができた ${ }^{7)}$.

また，諏訪市では「特定軟弱地盤対策住宅建設事業補 助金交付要綱」に基づき，指定された基礎対策工法（べ 夕基礎，杭打基礎（木杭等の摩擦杭，既製コンクリート 杭等の支持杭), 小口径鋼管による柱状改良, セメント 系固化材による柱状改良, 表層地盤改良, コマ型ブロッ ク，表層置換（いかだ工法含む））が施された場合に住 宅建設基準に適合したとして補助金が交付されている.

有明粘土が厚く堆積する地域では，支持杭や着底型の 地盤改良では工費が高い上に杭の抜け上がりや不同沈 下，境界での不陸の発生などの問題が生じるため, 非着 底型の深層改良工法も開発され，実際に有明海沿岸道路 の建設に採用されている ${ }^{8)}$.

\section{4 おわりに}

未改良の埋立地や低平地の地盤沈下対策は，既存の構
造物などが周辺に存在することなどから, その地域の沈 下の特徵を反映して策定されなければならない. 地盤沈 下への対応は，地盤改良工法が欠かせないものである. 最後に，地盤改良工法による地盤沈下対策の基本的な考 え方は以下のとおりである。

(1) 地盤沈下を根本的に止める.

(2) 地盤沈下範囲を限定する.

(3) 地盤沈下を許容し構造物側で対応する.

(4) 地盤沈下を緩和する.

地盤沈下が発生している埋立地や低平地の利用形態 を考慮した上で，種々の工法から選定または組み合わせ て対応することが望ましいと考える.

\section{最後に，次回からの内容について概説する，}

第 2 回では「地盤沈下のメカニズム」として, 土の構 造と圧密現象について, 室内試験の結果をもとに考察す る. 第 3 回は, 「地盤沈下と地域地盤特性」として, 詳 細な地盤調査がもたらすもの, 地域地盤が持つ個性を解 説する. 第 4 回では「代表的な地盤沈下対策方法」とし て，代表的な地盤沈下対策工法の 20 年間の進化（あゆ み）を紹介し解説する. そして最後の第 5 回では「地盤 沈下対策の新たなトレンド」として, 地盤沈下調査手法, 未改良地盤への対策, 期待される技術について解説し総 括を行う。

\section{参考文献}

1) H. Imanishi and M. Sugiyama, "Transition of ground improvement technologies in Japan, III : Subsidence measures of unimproved ground in the urban area", JSMC, Vol. 65, No.10, pp.752-757(2016).

2) Ministry of the Environment, Water and air quality stations, Ground subsidence area overview in Japan, pp17-19 (2016).

3) Sendai City Environmental Bureau, Environment of Sendai City, Performance Report 2014, pp37-42 (2015).

4) Miyagi Prefecture Living and Environment section, Pollution materials (ground subsidence ed.) pp21-24 (2016).

5) H. Hayashi and S. Nishimoto, "Advanced analytical for long-term settlement of peaty ground", Monthly report, Civil Engineering Research Institute for Cold Region, No.666, pp.11-19 (2008).

6) H. Imanishi, Y. Tsukidate and I. Kanazawa, "Ground subsidence properties of Shiogama clay and a proposal of countermeasure method for the subsidence", Proc. of the $11^{\text {th }}$ National Symposium on Ground Improvement, pp.91-96 (2014).

7) Ministry of the Environment, http://www.env.go.jp/water /jiban/directory/20nagano/suwa/h18_nagano1.html, (Accessed 9 April 2016).

8) T. Turu, K. Komanobe and K. Ryoukai, "Approach on soft ground measure of Ariake sea road Plan of the technology standard and utilization of the construction management $\sim$ Civil Engineering Journal, PWRC, Vol.52, No.10, pp.56-59 (2010). 